\title{
Information and communication resources of distance education
}

\author{
Raisa Bazaliy, ${ }^{1, *}$ \\ ${ }^{1}$ Don State Technical University, Rostov-on-don, 344000, Russia
}

\begin{abstract}
The author studies information and communication resources that increase students' academic and professional skills, their activity in creative research. The article considers new promising areas of cooperation between subjects of the educational process. The focus is on the study of forms and means of distance education at the technical university using educational and information platforms. The article summarizes the comparison of the use of interactive and active learning methods, and presents the results of the study. The following research methods were used: the analysis of scientific and theoretical, psychological and pedagogical literature on the topic of distance education, foreign and domestic experience in using multimedia and information content on the Internet, questionnaires, testing of bachelors in humanitarian and technical fields.
\end{abstract}

\section{Introduction}

Taking into account the increasing requirements for training bachelors in distance education, it has become urgent to improve information and communication resources that increase the educational and professional skills of users, their activity in creative research activities in modern conditions. The continuous growth of the information flow mobilizes teachers of the Don State Technical University to use innovative methods of e-learning in their professional activities. By organizing educational activities in order to prevent the spread of coronavirus infection, the university develops new promising areas of cooperation between subjects of the educational process, uses available information technologies and communication tools. The information and educational environment of the DSTU is widely represented by means of exchange of educational and professional information for effective traditional and distance education; organizational and methodological support is focused on the positive solution of educational abilities and needs of students, their adaptation in the modern world.

The purpose of the study is to study e-learning resources that increase the effectiveness of students' creative research activities, forms and means of distance education using educational and information platforms that helped students to overcome the difficulties of the information era.

Expanding the access of subjects of the learning process to the Internet educational content has changed the psychological and pedagogical tasks, i.e. strengthening the use of

\footnotetext{
* Corresponding author: rv7bazalii@mail.ru
} 
interactive and active teaching methods, changing electronic ways of presenting educational material to improve the perception of information and methodological orientation of the electronic educational environment of the DSTU as well as Zoom, Google, Whatsapp.Web, Discord services.

The scientific discourse discusses the applied Internet technologies of distance learning, analyzes the problems associated with the digitalization of the educational process. The research of foreign scientists O. Peters, R. Garrison, B. Holmberg, and D. Keegan substantiates the principles of distance education and structures models for organizing the e-learning process [1]. The importance of formalization of educational material, automation of training and standardization of behavioral reactions of participants in the educational process are noted in the concepts of the scientists, but the forms of pedagogical support for the creative development of students are not sufficiently disclosed.

F. Saba analyzes the creation of a communicative environment between students and teachers using information and communication technologies in his work. According to the scientist, overcoming the audio-visual barrier between subjects of distance education develops interaction and the desire for mutual dialogue between participants in the educational process [2]. R. Garrison notes the importance of interaction between students and trainees in the process of creating an information and communication environment [3]. The difficulties of using Internet resources and information and communication technologies in training are analyzed in studies by A. Gary, R. Boeder, G. Miller, B. Boles, S. Pilemalm, H. Mehraj [4-9]. M. Terisa, R. Costa, D. Senashenko, M. Senashenko indicate the forms and types of high-quality distance training of specialists in international corporations in technical and humanitarian areas [10, 11].

Scientists Y. Baranovskogo, Yu. Afanasyev, Yu.Kuznetsov consider information and communication technologies as a way to improve the quality of distance education [12-14]. Researchers A. I. Nazarov and O. V. Sergeeva analyze the use of educational technologies and e-learning platforms, the creation of network training modules, and the conditions for students to choose an educational trajectory [15]. For our research, the conditions indicated by representatives of the scientific community for the successful organization of the educational process, a comprehensive combination of traditional learning with the capabilities of distance technologies, are important.

\section{Materials and Methods}

During the stages of the experiment, the following methods were used: the study of scientific and theoretical, psychological and pedagogical literature on distance education, the analysis of foreign and domestic experience in using multimedia and information content on the Internet for e-learning. A survey and testing of bachelors in the humanitarian and technical fields were conducted. On the basis of a system-based approach to the digitalization of the educational process, practical tasks were developed, and the results of creative research activities of students in traditional and distance learning were analyzed.

The study involved 157 students of the DSTU: 62 of them are studying in the humanities, 95 - in technical departments. Since 2016, pedagogical disciplines have been taught in each course, and teaching materials from educational and information resources on the Internet have been introduced in experimental groups using interactive methods. Undergraduates of control groups in the humanities and technical departments were taught pedagogical disciplines traditionally, using active teaching methods. The results of the study were analyzed in 2020, as well as effective interactive and active teaching methods, forms and means of improving the perception of the methodological orientation of educational and information platforms on the Internet using distance learning technologies were identified. 


\section{Results and discussion}

By analyzing non-traditional sources of information, bachelors develop an understanding and significance of independent work, and open new horizons for creative research activities. Modern information technologies and new forms of education consolidate the necessary professional skills of students, form experience in the educational and professional direction.

In our research, studying pedagogical disciplines, students strive not only to actively learn and implement knowledge and skills, but also to understand the skills they have acquired as well as their attitude to various types of activities. When testing students of the 3-4 courses: 27-from humanities, 43 - from technical departments, we took into account the personal abilities and needs of respondents; analysis of the test results showed the following (table.1). Data is given as a percentage.

Table 1. Students' awareness of their attitude to various types of activities.

\begin{tabular}{|l|c|c|}
\hline & $\begin{array}{c}\text { Humanitarian } \\
\text { departments }\end{array}$ & $\begin{array}{c}\text { Technical } \\
\text { departments }\end{array}$ \\
\hline $\begin{array}{c}\text { Novelty of results in creative research } \\
\text { activities }\end{array}$ & 34 & 39 \\
\hline $\begin{array}{c}\text { Understanding the problem and seeing } \\
\text { ways to solve it }\end{array}$ & 38 & 35 \\
\hline $\begin{array}{l}\text { Striving for independence in educational } \\
\text { and professional activities }\end{array}$ & 28 & 26 \\
\hline
\end{tabular}

In the March 2020, the forced transition to a remote mode of work made significant changes in the construction of the content of pedagogical disciplines, information methods of transmitting information in the context of increased independent work of students, and changes in the role of the teacher. Interactive and active learning methods were used in the substantive resource of e-learning; expanded the educational and informative field that meets the needs of students - in the informational one; activated interactive interaction of subjects of the educational process - in the organizational one.

In the experimental part, 31 fourth-year students of humanities and technical departments analyzed the substantive resource of pedagogical disciplines, electronic educational complexes of the information and educational environment of distance learning at the DSTU. In our study, the survey revealed the following indicators of significance for respondents of educational and methodological materials based on information and communication technologies (table 2).

Table 2. Significance of educational materials based on information and communication technologies for students.

\begin{tabular}{|l|l|l|}
\hline & Humanitarian departments & \multicolumn{1}{|c|}{ Technical departments } \\
\hline Textbooks & $\begin{array}{l}\text { creating a comfortable learning } \\
\text { environment, the ability to } \\
\text { formulate thoughts correctly }\end{array}$ & $\begin{array}{l}\text { providing a high-quality level of } \\
\text { training, visual problem solving } \\
\text { using algorithms }\end{array}$ \\
\hline Lecture series & $\begin{array}{l}\text { activation of mental activity, } \\
\text { development of information } \\
\text { perception skills }\end{array}$ & $\begin{array}{l}\text { comparison of theory with technical } \\
\text { equipment finding approximate } \\
\text { approaches to problem solving }\end{array}$ \\
\hline Workshop & $\begin{array}{l}\text { the emergence of a platform } \\
\text { for discussion, development of } \\
\text { critical thinking and } \\
\text { information synthesis }\end{array}$ & $\begin{array}{l}\text { possibility of constructive } \\
\text { independent use of formulas and } \\
\text { graphs for solving problems }\end{array}$ \\
\hline Control diagnostics & $\begin{array}{l}\text { information openness, self- } \\
\text { disclosure as a person, self- } \\
\text { control of knowledge, analysis }\end{array}$ & $\begin{array}{l}\text { activation of logical activity, self- } \\
\text { assessment of the understanding of } \\
\text { algorithms for working with the }\end{array}$ \\
\hline
\end{tabular}




\begin{tabular}{|l|l|l|}
\hline & of abilities & material \\
\hline Creative task & $\begin{array}{l}\text { the ability to improvise, to find } \\
\text { important information }\end{array}$ & $\begin{array}{l}\text { development of creativity, } \\
\text { improvement of practical skills }\end{array}$ \\
\hline $\begin{array}{l}\text { Multimedia and } \\
\text { interactive } \\
\text { presentations }\end{array}$ & $\begin{array}{l}\text { timulation of subject-image } \\
\text { memory, reasonableness of } \\
\text { questions; variety of forms of } \\
\text { graphic information }\end{array}$ & $\begin{array}{l}\text { increase in the coefficient of } \\
\text { learning material assimilation, } \\
\text { alignment of questions; } \\
\text { ready-made drawings ways of } \\
\text { thinking to solve problems }\end{array}$ \\
\hline $\begin{array}{l}\text { Demo and training } \\
\text { slides }\end{array}$ & $\begin{array}{l}\text { illustrative function, help in } \\
\text { the perception of educational } \\
\text { material }\end{array}$ & $\begin{array}{l}\text { creating a logical and visual } \\
\text { representation of the objects under } \\
\text { study }\end{array}$ \\
\hline List of references & $\begin{array}{l}\text { development of cognitive } \\
\text { activity, selective finding of } \\
\text { the necessary material }\end{array}$ & $\begin{array}{l}\text { a reference point for self-education, } \\
\text { improving information literacy, } \\
\text { searching for sources to consolidate } \\
\text { the received material }\end{array}$ \\
\hline Glossary & $\begin{array}{l}\text { expanding your horizons, } \\
\text { understanding the in-depth } \\
\text { meaning of words }\end{array}$ & $\begin{array}{l}\text { therminology, formulas, and memory } \\
\text { development }\end{array}$ \\
\hline
\end{tabular}

The results of the study has confirmed that the educational materials of the information and educational environment of the DSTU are changing and adapting to the changing conditions of distance education. For example, for the study of the bachelor's discipline "Philosophy and History of Education", the author has developed creative tasks in the form of research work with citing sources, such a system of practical classes in this discipline forms the experience of students' creative research activities and performs the following functions:

- educational: the study of new forms and methods that are used in the conditions of informatization of society for the development of the creative and research orientation of students;

- practical: finding a creative solution to a contextual problem in new conditions, implementing a personal search path in solving a problem-solving task;

- developmental: independent comparing and contrasting of ways to solve a creative task, development of reflection and creative entry into the proposed situation;

- educational: education of responsibility and purposefulness, communicative cooperation, respect and patience in dialog communication, independence.

Systematic reproduction of new forms of e-learning is aimed at improving the effectiveness of distance education, the development of creative research activities of bachelors. Students of the 1st-4th courses in humanities and technical departments were given a task related to determining the usefulness of interactive and active forms of learning used in the educational process for personal development. Respondents identified the following advantages of the analyzed forms of education (table 3 ).

Table 3. Advantages of using interactive and active forms of learning in distance education.

\begin{tabular}{|l|l|l|}
\hline & \multicolumn{1}{|c|}{ Humanitarian department } & \multicolumn{1}{c|}{ Technical department } \\
\hline Project method & $\begin{array}{l}\text { organization of educational } \\
\text { projects, production of new ideas }\end{array}$ & $\begin{array}{l}\text { development of critical } \\
\text { thinking, self-reliance in project } \\
\text { planning }\end{array}$ \\
\hline Case method & $\begin{array}{l}\text { artistic realization of the case } \\
\text { tasks, participation in the search } \\
\text { process }\end{array}$ & $\begin{array}{l}\text { creating case tasks of various } \\
\text { levels of complexity }\end{array}$ \\
\hline $\begin{array}{l}\text { The "brainstorming" } \\
\text { method }\end{array}$ & $\begin{array}{l}\text { stimulating creative activity, } \\
\text { analyzing and expressing your } \\
\text { point of view }\end{array}$ & $\begin{array}{l}\text { finding solutions to a problem, } \\
\text { developing new tools, brand or } \\
\text { logo details }\end{array}$ \\
\hline Research method & heuristic conversation, solving & problematic lecture, the solution \\
\hline
\end{tabular}




\begin{tabular}{|l|l|l|}
\hline & creative problems & of inventive problems \\
\hline $\begin{array}{l}\text { Role-playing and } \\
\text { business games }\end{array}$ & motivated learning process & motivated learning process \\
\hline Discussion & $\begin{array}{l}\text { development of communication } \\
\text { interaction }\end{array}$ & $\begin{array}{l}\text { analysis of the proposed ideas, } \\
\text { active work with educational } \\
\text { material }\end{array}$ \\
\hline
\end{tabular}

The bachelors marked the methods that develop their creative thinking, independence in the organization of educational and professional activities and problem solving, planning targeted cognitive research, and organizing creative cooperation between subjects of the educational process.

In the context of our research, it became important to use the information resource of pedagogical disciplines as part of distance education for this purpose, we expanded the informative field that develops the desire for independence among subjects of the educational process, and increased the activity of future specialists in drawing up an individual educational vector of creative self-development. Information and communication technologies allow modern students to successfully use the educational content of the Internet, to activate the mental activity of users of the world's media and educational space. During the survey the respondents identified for successful creative research activities of the world digital library, an educational project Coursera, an educational project "Arzamas", non-profit academic and educational project "Lectorium", television project "ACADEMIA", Internet resource "EDX", online university "Skillbox".

After studying educational and information platforms and electronic libraries by bachelors, electronic testing was conducted for students of 3-4 courses in Humanities and technical areas. When conducting electronic testing, students were asked a question related to the advantage of using electronic interaction tools. Respondents noted that $39 \%$ of students use information together, 34\% cooperate in identifying interactive problems and finding acceptable solutions to them, and $27 \%$ share common ideas and create educational projects that develop all types of student activities.

University teachers organize video conferences in Zoom and strive to improve the effectiveness of interactive interaction between subjects of the educational process, using various electronic services and resources of the University. The majority of respondents $(47 \%)$ noted interesting discussions. For this purpose, teachers and students jointly developed the structure of multimedia interaction and the algorithm of information and communication interaction; $24 \%$ - the ability to ask a meaningful question on the topics discussed, 29\% - reflection training, which helps to realize their achievements, stimulating the creation of new creative educational projects. The analysis of testing showed positive dynamics of development of thinking, abilities in finding creative solutions to contextual problems, changes in the vector of mental operations in individual creative research activities.

\section{Conclusion}

The study confirmed the importance for students not just to get ready-made knowledge, but to be an active participant in interactive interaction, to successfully search for alternative sources of information independently.

The media and educational space of the DSTU has created opportunities for students to present their achievements and new educational results in the information space of the University. Over the course of four years of study, bachelors in all fields have significantly increased their rating of achievements, taking prizes in scientific and practical conferences and publishing in the journal "Young researcher of the Don". Successful organization of the educational process, a complex combination of traditional full-time education with the 
possibilities of educational technologies of distance learning increased the activity of creative research activities of students. The free choice of e-learning tools using information and communication technologies provided ample opportunities to demonstrate the achievements of students, to participate in creative educational projects for active bachelors of humanities and technical departments.

\section{References}

1. O. Peters, Distance Education: International Perspectives (London Croom Helm, 1983)

2. F. Saba, Handbook of distance education (Lawrence Erlbaum Associate Publishers, New Jersey, 2003)

3. R. Garrison, International Review of Research in Open and Distance Learning 1, 3 -15 (2000)

4. A. Gary, Encyclopaedia Britannica (2016) https://www.britannica.com/topic/distancelearning

5. $\mathrm{P}$

Boeder,

First

Monday

7

https:/firstmonday.org/ojs/index.php/fm/article/view/969/890

6. G. Miller, History of Distance Learning. Education Guidance. American Inter Continental University Online (2014) https://www.worldwidelearn.com/educationarticles/history-of-online-learning.htm

7. B. Boles, Columbia Social Work Review 4, 69-79 (2013) doi.org/10.7916/D88P5Z1B

8. S. Pilemalm, Information Technology for Non-Profit Organizations (2002) https://www.diva-portal.org/smash/get/diva2:20857/FULLTEXT01.pdf

9. H. Mehraj, A., Bhat, International Journal of Humanities and Social Science Invention 3, 56-64 (2014)

10. R.L. Da Costa, Ml.Al. Terisa, Pedagogy and psychology of education 4(4), 32-40 (2018) DOI: 10.18413/2313-8971-2018-4-4-0-3

11. D. Senashenko, M. Senashenko, RUDN Journal of Informatization of Education, 14(1), 42-48 (2017)

12. Yu.S. Branovsky, Information innovative technologies in professional education (KubSTU, Krasnodar, 2001)

13. Yu.N. Afanasiev, Through forms to meanings: on a new University educational model (RSUH, Moscow, 2006)

14. I.E. Vostroknutov, Yu.K. Kuznetsov, Pedagogical Informatics Moscow 2, 43-47 (1994)

15. A.I. Nazarov, O.V. Sergeeva, Zh. open education, 42-49 (2016) https://cyberleninka.ru/article/n/preimuschestva-distantsionnyh-obrazovatelnyhtehnologiy-vzglyady-studentov-i-prepodavateley 